\title{
Wild-gathered fungi for health and rural livelihoods
}

\author{
Miriam de Román ${ }^{1 *}$, Eric Boa ${ }^{1}$ and Steve Woodward ${ }^{2}$ \\ ${ }^{1}$ CABI Bioscience, Bakeham Lane, Egham, Surrey TW20 9TY, UK \\ ${ }^{2}$ School of Biological Sciences, University of Aberdeen, Plant and Soil Science, St Machar Drive,
}

Aberdeen AB24 3UU, UK

\begin{abstract}
Fungi are a good source of digestible proteins and fibre, are low in fat and energy and make a useful contribution to vitamin and mineral intake. In terms of current dietary advice, $80 \mathrm{~g}$ fungi represent one portion of vegetables. Dried fungi and concentrated extracts are also used as medicines and dietary supplements. Some species show strong anti-tumour and antioxidant activity by enhancing various immune system functions and lowering cholesterol levels. Nevertheless, there are also some safety concerns. Edible species might be mistaken for poisonous ones, high heavy-metal concentrations in wild edible fungi (WEF) are a known source of chronic poisoning and the consumption of WEF can contribute markedly to the radiocaesium intake of human subjects. Some regions of Europe have a strong WEF tradition, especially eastern Europe. In the UK the consumption of wild fungi is considered of minor importance. Only one-third of adults consume fungi (cultivated species and WEF) throughout the UK; the average intake of fungi in the UK is estimated to be $0 \cdot 12 \mathrm{~kg}$ fresh weight per capita per year. At least eighty-two species of wild fungi are recorded as being consumed in the UK, although certain species (e.g. chanterelle (Cantharellus cibarius), cep (Boletus edulis), oyster mushroom (Pleurotus ostreatus)) are favoured over others. Although WEF are not essential components in the daily diet, they are a nutritionally-valuable addition to the range of vegetables consumed, and their role in helping to avert food shortages in less-favoured areas should be definitely considered.
\end{abstract}

Wild edible fungi: Medicinal fungi: Nutrition: Safety: Health

Wild edible fungi (WEF) are a natural resource with a high nutritional and economic value. Although collection is often regarded as a hobby, recent studies confirm that they are an important source of food and income in both developing and developed countries (Hosford et al. 1997; Wong et al. 2001; Boa, 2004).

Attitudes towards WEF are very different around the world. According to Boa (2004) about 1200 species of fungi are used in eighty-five different countries for their gastronomic value and/or medicinal properties. China, Japan and eastern European countries are particularly enthusiastic collectors and consumers, and have developed a robust marketing network in order to satisfy the high demand. In northern and western Europe and North America WEF have traditionally been mistrusted, although trends vary among countries. In central America some wild fungi are revered as sacred objects (Wasson, 1968). Studies in Africa reveal that the knowledge and use of
WEF is widespread (Yorou \& De Kesel, 2001; Kuyper, 2002).

The most remarkable WEF species in terms of world trade are the black truffle (Tuber melanosporum), which is exported from France, Italy and Spain, the matsutake (Tricholoma matsutake and relatives), which is sent to Japan from the USA, Canada, Mexico, China and neighbouring countries, and the boletes (Boletus spp.) and chanterelles (Cantharellus cibarius), which are widely appreciated.

In terms of nutrition WEF are rich in protein and have considerable value as a source of dietary fibre because of both their high fibre content and their unique fibre composition (Cheung, 1997). Some medicinal species are widely used in traditional and alternative medicines to heal a broad range of diseases; Ganoderma lucidum, for example, is especially esteemed in China and Japan (Molitoris, 2002).

\footnotetext{
Abbreviations: DW, dry weight; WEF, wild edible fungi.

*Corresponding author: Dr Miriam de Román, fax + 441491 829100, email miriamderoman@hotmail.com
} 
The present paper gives a global perspective on the nutritional and medicinal value of WEF, addresses safety concerns and describes their consumption and role in rural livelihoods worldwide.

\section{The nutritional value of fungi}

Many studies have been undertaken on the nutritional composition of cultivated edible fungi and WEF (for a summary of the most informative of these studies, see Table 1 and for further information, see Mukhiibi, 1973; Seeger et al. 1983; Coli et al. 1988; Mattila et al. 1994; Outila et al. 1999; Vetter, 1999; Ilievska \& Petrovska, 2000; Caglarirmak et al. 2002; Sadler, 2003; Sanmee et al. 2003; Yildiz et al. 2005).

In general, edible fungi contain $850-950 \mathrm{~g}$ water $/ \mathrm{kg}$ fresh weight and (g/kg dry weight (DW)) 160-350 protein, 20-60 fat and 280-399 carbohydrate. However, the wide variety and abundance of minerals are the most characteristic features of fungi; they are useful sources of $\mathrm{Cu}, \mathrm{Fe}, \mathrm{K}$, $\mathrm{Mg}$, Se, $\mathrm{P}$ and $\mathrm{Zn}$ in the human diet and are very low in Na. They are a source of unsaturated fatty acids (particularly oleic and linoleic acids), contain high amounts of dietary fibre and are low in energy (1.42-5.46 MJ (340$1310 \mathrm{kcal}) / \mathrm{kg}$ ). The proportion of protein, the amino acid index and the quantity of minerals appears to be greater in the cap than in the stem (Coli et al. 1988). In terms of current dietary advice, $80 \mathrm{~g}$ fresh fungi is equivalent to one portion of vegetables (Sadler, 2003) and a serving (100 g) of fungi guarantees 9 (fresh Agaricus bisporus)-40 (dried Boletus spp.) \% RDA for dietary fibre (Manzi et al. 2001).

The nutritional value of proteins is usually very high in the majority of fungi (Ilievska \& Petrovska, 2000), and fungal proteins are considered to be of equal quality to those of animal origin (Longvah \& Deosthale, 1998). León-Guzmán et al. (1997) have shown that the protein contents $(\mathrm{g} / \mathrm{kg})$ of fresh Amanita rubescens, Boletus frostii, Lactarius indigo and Ramaria flava collected in Mexico are higher (190-350) than those of wheat (132) or milk (252). Some exceptions exist; in Lentinula edodes or Termitomyces spp. the protein quality is inferior to that of grain legumes and cereals, but is still comparable with that of many vegetables (Mukhiibi, 1973; Longvah \& Deosthale, 1998).

Some species, such as Termitomyces umkowaani and $T$. sagittaeformis, contain all the essential amino acids (Botha \& Eicker, 1992). Other species lack one or more of the essential amino acids; in $T$. reticulatus four essential amino acids (isoleucine, leucine, methionine and cytosine) are severely limiting (Botha \& Eicker, 1992); in Hericium erinaceus methionine and tryptophan are absent (Eisenhut et al. 1995). In the fungi analysed by Agrahar-Murugkar \& Subbulakshmi (2005) phenylalanine was found to be the limiting amino acid and leucine the most abundant amino acid. León-Guzmán et al. (1997) have recorded high levels of free lysine in Amanita rubescens, Boletus frostii, Lactarius indigo and Ramaria flava, making these species valuable additions to the human diet. Tricholoma terreum and $T$. portentosum are particularly rich in glutamic acid $(220 \mathrm{mg} / \mathrm{g}$ total amino acids), like many other fungi (Díez \& Álvarez, 2001). The high concentrations of glutamic acid in $T$. terreum and $T$. portentosum probably contribute most to their characteristic flavour. Another possible source of the precursor flavour compounds would be the presence of unsaturated fatty acids, particularly linoleic acid (Díez \& Álvarez, 2001).

Several studies have confirmed that fungi make a useful contribution to vitamin intake, particularly the $\mathrm{B}$ vitamins and vitamins $\mathrm{D}$ and $\mathrm{K}$, and in some cases vitamins A and C (Sadler, 2003; Sanmee et al. 2003). Mattila et al. (1994) have shown that Cantharellus cibarius and C. tubaeformis contain high amounts of ergocalciferol (128 and $298 \cdot 2 \mu \mathrm{g} / \mathrm{kg}$ fresh weight respectively), possibly because in the genus Cantharellus the pileus and gills are often more effectively exposed to light than they are in other species of fungi. The influence of illumination conditions in determining ergocalciferol content is a factor that should be taken into account in the case of cultivated fungi. Outila et al. (1999) have shown that human subjects can easily absorb ergocalciferol from lyophilized and homogenized Cantharellus tubaeformis. Thus, for some groups, for example vegetarians or individuals allergic to fish, fungi can be an important dietary source of vitamin D.

Fungi rank amongst the vegetables with the lowest $\mathrm{Na}$ content (Seeger et al. 1983). The Na contents of plants vary between 200 and $2000 \mathrm{mg} / \mathrm{kg}$, while in some meat and meat products $\mathrm{Na}$ contents range from 10000 to $22000 \mathrm{mg} / \mathrm{kg}$. The fruit bodies of Agaricus species contain on average $396 \mathrm{mg} \mathrm{Na} / \mathrm{kg}$ (Vetter, 2003b), which is of great nutritional benefit to the consumer.

The nutritional value of fungi can be affected by the method of preservation. Manzi et al. (2001) have compared the nutritional value of Agaricus bisporus (fresh, canned and deep-frozen), fresh Pleurotus ostreatus and dried Boletus spp. Cooked dried Boletus spp. were found to have the highest nutritional value, although this effect is essentially a result of insufficient rehydration. On the other hand, cooked deep-frozen Agaricus samples have lower amounts of protein $(19 \mathrm{~g} / \mathrm{kg})$ and fat $(2.6 \mathrm{~g} / \mathrm{kg})$ than fresh (protein $20 \cdot 1 \mathrm{~g} / \mathrm{kg}$, fat $4.5 \mathrm{~g} / \mathrm{kg}$ ) or canned (protein $20.4 \mathrm{~g} / \mathrm{kg}$, fat $4.2 \mathrm{~g} / \mathrm{kg}$ ) Agaricus. It is probable that the structural damage to the cells, occurring during the deepfreezing process, promotes nutrient loss and causes the small post-cooking yield (Manzi et al. 2001).

Individual species appear to have similar nutrient concentrations in different forest ecosystems (Rudawska \& Leski, 2005). Sanmee et al. (2003) have found that the chemical and nutritional composition of WEF collected in sub-tropical forests of Thailand are within the same order of magnitude as that measured in fungi collected in more temperate regions.

Finally, fungi can also have a role as functional foods, known as 'nutraceuticals', which are those materials that are beneficial, but not absolutely vital, for the human body (Tudge, 2001). Modern diets are based on relatively few domesticated plants, which in terms of biochemical composition tend to be blander than their wild counterparts, and some theories suggest a return to more primitive eating habits, much closer to those of man's hunter-gatherer ancestors (Tudge, 2001). 


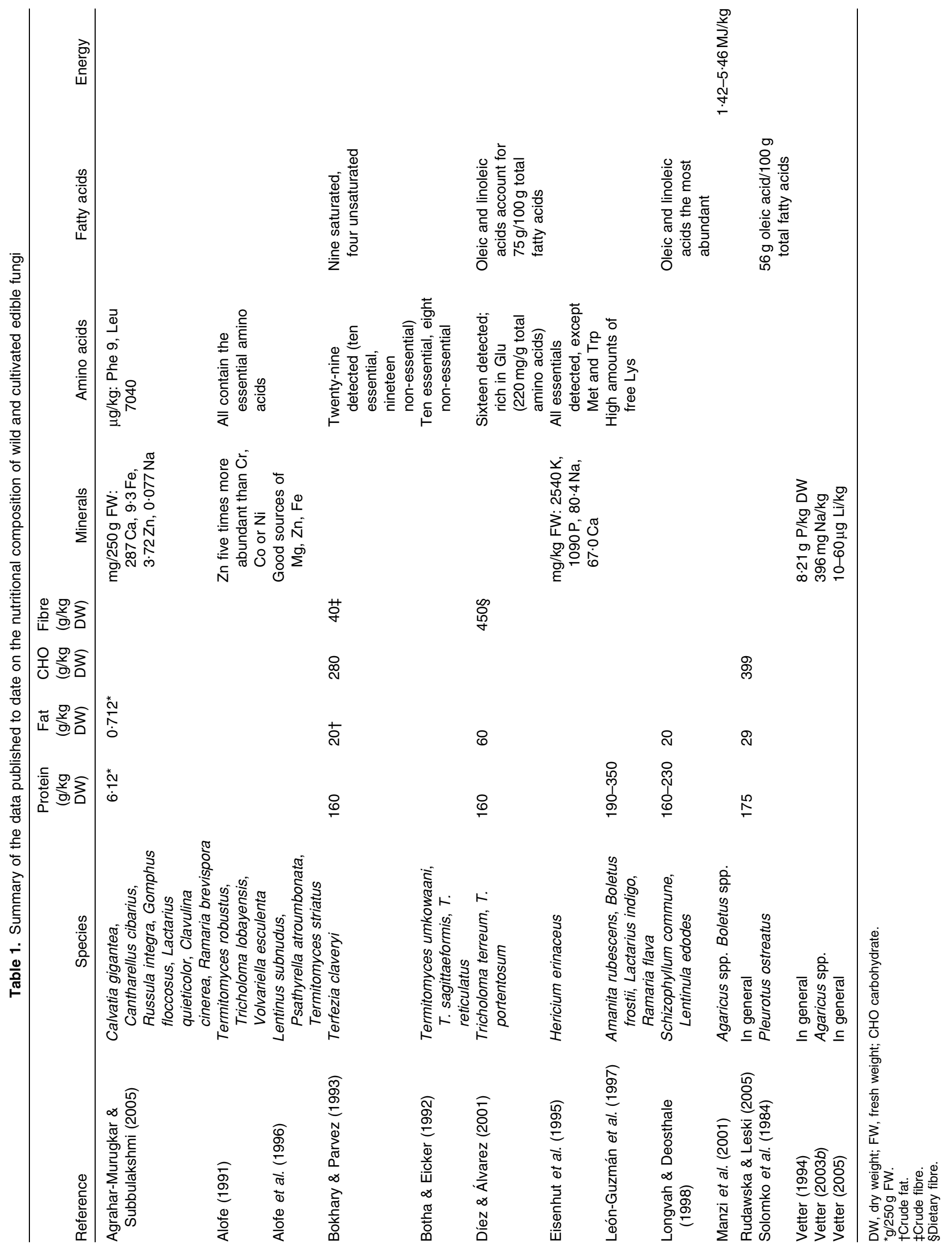




\section{The value of fungi as medicines}

Fungi are well known for their medicinal properties. From ancient times Oriental traditional medicine has stated that medicine and food have the same origin. Amongst the many species used in medicine, the most common are Claviceps purpurea, Cordyceps sinensis, Ganoderma lucidum, Laricifomes officinalis, Lentinula edodes and Trametes versicolor (Molitoris, 2002).

Fungi are a good source of digestible proteins and fibre in the form of chitin, which has potential in lowering cholesterol (Sadler, 2003). The intake of fungi has also been shown to be effective in cancer prevention. Ikekawa (2001) has reviewed studies of the anti-tumour activity of fungi undertaken at the National Cancer Research Institute of Japan since 1966. Several anti-tumour polysaccharides have been isolated, the most important of which is lentinan, a $\beta$-1,3-glucan isolated from Lentinula edodes (shiitake), which is used clinically in Japan. Lentinan may enhance various immune system functions, such as increasing production of T-helper cells and macrophages (Sadler, 2003). Other popular edible fungi, such as Flammulina velutipes (enokitake) and Hypsizygus marmoreus (bunashimeji), also have high anti-tumour activity and a preventive effect in tumour metastasis (Ikekawa, 2001). An epidemiological study carried out in the Nagano Prefecture, Japan, has indicated that the death rate from cancer among farmers producing Flammulina velutipes as a main occupation is markedly lower than that of the other subjects studied. The cancer prevention effect of Hypsizygus marmoreus has been investigated in a bioassay with mice injected with a carcinogen. Of the thirty-six control mice twenty-one were found to have developed tumours, whereas only three of the thirty-six mice that had been fed on H. marmoreus were found to have tumours (Ikekawa, 2001).

Antioxidant activity of WEF has also been recorded. In a study by Lakshmi et al. (2004) the four fungi examined, Phellinus rimosus, Pleurotus florida, Pleurotus sajor-caju and Ganoderma lucidum, were reported to show antioxidant activity. Cellular damage caused by reactive oxygen species has been implicated in several diseases, and hence the antioxidant properties of fungi may play an important role in human health.

Other studies that have focused on the medicinal properties of fungi include that of Ling et al. (1990), who have found that Flammulina velutipes is protective against increased serum cholesterol level and promotes the formation of $\mathrm{Hb}$ in rats. Ooi (2001) has focused on the effects of selected Chinese medicinal fungi, i.e. the immunomodulation and anti-tumour activity of Tricholoma giganteum, the blood pressure-lowering action and mechanism of Volvariella volvacea and the liver protective effect of Trametes versicolor.

\section{Safety concerns when eating wild edible fungi}

Although the benefits of eating wild fungi are clear, there are also safety concerns that have to be taken into consideration.
It is clearly of great importance that edible species are not mistaken for poisonous ones. In most cases only mild poisoning occurs, with stomach upsets and sickness. Nevertheless, in a few cases the consequences may be fatal, as in the case of Amanita phalloides, A. verna, A. virosa, Cortinarius orellanus or Galerina marginata. Some mushrooms contain natural toxins, such as nitrosamines, which are particularly abundant in Boletus edulis, and haemaglutinins, which are destroyed by cooking (Sadler, 2003). Some fungi are thus poisonous when raw, but edible when cooked properly, such as Morchella spp. or Gyromitra spp. Other fungi are only poisonous when consumed together with alcohol, e.g. Coprinus atramentarius. Psycho-active fungi, e.g. Amanita muscaria or Psilocybe spp., can have adverse effects on brain chemistry and mental health and can produce other toxic symptoms in the body (Sadler, 2003).

High heavy-metal concentrations in WEF are also a known source of chronic poisoning, although peeling and washing caps and stalks can reduce their heavy metal contents by about 30-40\% (Zrodowski, 1995). Saprophytic species usually show higher concentrations of heavy metals than mycorrhizal species (García et al. 1998; Melgar et al. 1998; Alonso et al. 2000, 2003), while fungal species growing on wood tend to have lower concentrations of heavy metals than those growing on soil (Alonso et al. 2003). Cultivated species accumulate lower concentrations of heavy metals than wild species because their mean life span is shorter (Zrodowski, 1995; Alonso et al. 2000). The hymenophore shows higher metal concentrations than any other part of the fruit body (Melgar et al. 1998; Alonso et al. 2000, 2003), and the heavy-metal concentration of the cap exceeds that of the stipe (Svoboda et al. 2000; Zimmermannova et al. 2001).

Some fungi are well known to accumulate high concentrations of Hg; Agaricus and Macrolepiota have been shown to contain $2.92 \mathrm{mg} / \mathrm{kg}$ DW, and Lepista $(3.02 \mathrm{mg} / \mathrm{kg}$ DW) and Lycoperdon perlatum $(2.94 \mathrm{mg} / \mathrm{kg} \mathrm{DW})$ could also fall into this category (Vetter \& Berta, 1997). It is important to note that the recommended maximum $\mathrm{Hg}$ intake for an adult is, according to the WHO standard, $0.03 \mathrm{mg} / \mathrm{kg}$ food consumed (Vetter \& Berta, 1997).

The genus Agaricus is not only an efficient bioaccumulator of $\mathrm{Hg}$, but also of Cd (Melgar et al. 1998) and Ag (Falandysz et al. 1994). Agaricus macrosporus has been shown to have the highest concentrations of $\mathrm{Cd}$ (68.96 and $36.84 \mathrm{mg} / \mathrm{kg}$ DW for the hymenophore and the rest of the fruiting body respectively) among thirteen WEF species collected in Spain (Melgar et al. 1998). A. campestris and A. augustus have also been reported to contain the highest concentrations of $\mathrm{Ag}$ among wild-grown fungi studied in northern Poland $(35 \mathrm{mg} / \mathrm{kg} \mathrm{DW}$ and $2 \cdot 0-6.9 \mathrm{mg} / \mathrm{kg} \mathrm{DW}$ respectively; Falandysz et al. 1994).

Alonso et al. (2000) have analysed the $\mathrm{Hg}$ content of eight species of fungi from Spain: four mycorrhizal species (Boletus pinicola, Cantharellus cibarius, Lactarius deliciosus, Tricholoma portentosum); four saprophytes, two cultivated (Agaricus bisporus and Pleurotus ostreatus) and two from the wild (Agaricus campestris and Macrolepiota procera var. procera). Of the samples $90.2 \%$ were found to exceed the limit established by legislation, although 
$70 \%$ of the toxicity of $\mathrm{Hg}$ was reported to disappear with cooking. In order to avoid a risk for human health, Alonso et al. (2000) have recommended the elimination from the diet of the hymenophore portions of Boletus pinicola and Macrolepiota procera var. procera and have suggested that Agaricus campestris should not be consumed at all.

In the study by Falandysz et al. (2004) in Poland Leccinum rufum was shown to have accumulated the greatest concentrations of $\mathrm{Hg}$ among the WEF analysed. The concentrations of $\mathrm{Hg}$ for all WEF studied were found to exceed the human tolerance limit set for dried plant foodstuffs; when expressed on a fresh weight basis, the concentrations were found to be below the tolerance limit for four of the fifteen species analysed. However, these data must be interpreted cautiously. The rates of WEF consumption in Poland have been estimated at $7 \mathrm{~kg}$ fresh weight per household per year, with a maximum of $10 \mathrm{~kg} /$ year for some individuals $(28 \mathrm{~g} / \mathrm{d})$. An estimate of the daily intake of $\mathrm{Hg}$ from WEF consumption indicates that the flesh of WEF may not pose hazards to human health even at a maximum consumption rate of $28 \mathrm{~g} / \mathrm{d}$.

Considerable contamination of most WEF from a heavily-polluted area in Slovakia has been observed mainly for $\mathrm{Hg}$ and $\mathrm{Cd}$ (Svoboda et al. 2000). Many of the WEF were found to exceed the Slovak food statutory limits for $\mathrm{Cd}, \mathrm{Hg}, \mathrm{Pb}$ and $\mathrm{Cu}$ content set at 2, 5, 10 and $80 \mathrm{mg} / \mathrm{kg}$ DW respectively. Thus, the authors have recommended that some WEF species from the polluted area should not be consumed at all. Samples of WEF fruiting bodies have also been collected in an emissions area for a $\mathrm{Hg}$ and $\mathrm{a} \mathrm{Cu}$ smelter in Slovakia (Zimmermannova et al. 2001). In this case Slovak food statutory limits were reported to have been surpassed by $93.3,82 \cdot 0,15.3$ and $9.8 \%$ for $\mathrm{Hg}, \mathrm{Cd}$, $\mathrm{Pb}$ and $\mathrm{Cu}$ respectively. In Poland $\mathrm{Cd}$ contamination has been found to be particularly high for fresh Cantharellus cibarius collected from all regions; dried Boletus edulis and Boletus scaber were also found to exceed the permitted limits of $1 \mathrm{mg} / \mathrm{kg}$ DW (Statkiewicz \& Gayny, 1994). $\mathrm{Pb}$ concentrations in Xerocomus badius $(5 \cdot 4 \mathrm{mg} / \mathrm{kg}$ DW) have also been reported to exceed both Polish $(2 \mathrm{mg} /$ $\mathrm{kg} \mathrm{DW})$ and European (3 $\mathrm{mg} / \mathrm{kg}$ DW) tolerance limits (Rudawska \& Leski, 2005). In north-west Russia the fungi growing over an area of $\leq 3000 \mathrm{~km}^{2}$ around a smelter complex have been declared unsuitable for human consumption because of the elevated $\mathrm{Ni}$ concentrations caused by the smelter dust emissions. The fungi gathered in the polluted forests were found to contain fifteen to forty times more $\mathrm{Ni}$ than the background level (Barcan et al. 1998).

García et al. (1998) have analysed the $\mathrm{Pb}$ content in WEF collected from north-west Spain, and have found that Coprinus comatus contain the highest concentrations, reflecting the effects of traffic pollution; this species could, therefore, be considered an indicator of $\mathrm{Pb}$ contamination. It was recommended that wild fungi, especially saprophytes, should not be consumed within an approximate distance of $50 \mathrm{~m}$ from the main roads. Isiloglu et al. (2001) have confirmed that the effects of traffic pollution are mainly reflected in the $\mathrm{Pb}$ contents of fungi. Nevertheless, Svoboda et al. (2000) have suggested that no single species of fungi can be considered as a precise indicator of environmental pollution with heavy metals, but fruiting bodies can be useful for distinguishing between polluted and unpolluted sites.

$\mathrm{The} \mathrm{Cd}, \mathrm{Pb}$ and $\mathrm{Hg}$ contents of twenty-four WEF species collected in primary forests of Latin America have been shown to be surprisingly similar to those found in fungi collected in polluted urban areas in Europe (Michelot et al. 1999). These results suggest long-distance dry or wet deposition of heavy metals across the globe.

Not all studies indicate that consumption of WEF poses a risk in relation to the intake of heavy metals. In the UK a survey of the concentrations of twelve metals and other elements in WEF has concluded that the estimated dietary exposures are within relevant guidelines on safe exposures (Joint Food Standards and Safety Group, 2000). In Spain $\mathrm{Cu}$ and $\mathrm{Zn}$ contents have been determined for twenty-eight species of fungi (Alonso et al. 2003). The highest metal concentrations were found in Calvatia utriformis, Macrolepiota procera, Agaricus macrosporus and Lactarius deliciosus, but when the $\mathrm{Cu}$ and $\mathrm{Zn}$ concentrations were compared with levels set by legislation, it was concluded that the consumption of these fungi poses no toxicological risk.

Another risk that should not be overlooked is that the consumption of WEF can contribute markedly to the radiocaesium intake of human subjects, because radiocaesium concentrations in fungi are higher than those in other foodstuffs. Higher radiocaesium activity usually occurs in mycorrhizal species as compared with saprotrophic or parasitic species (Barnett et al. 1999).

Giovani et al. (2004) have shown that since the Chernobyl accident in 1986 the average concentration of ${ }^{137} \mathrm{Cs}$ in wild fungi does not seem to be decreasing markedly over time, but the radionuclide physical decay is moving from fungi with more superficial mycelia to those with deeper mycelia. After the Chernobyl accident Vasser et al. (1992) recommended that Ukrainians should stop picking WEF because the levels of radioacaesium in WEF were very high. Surprisingly, in an online questionnaire carried out by Druzhinina \& Palma-Oliveira (2004) among fungi pickers from different regions in Europe, respondents from eastern European countries were found to have a higher perceived global contamination of WEF and a higher perception of the Chernobyl global influence, but to show the highest rates of collection and consumption of WEF, while possessing the lowest perception of possible personal harm.

In contrast, in countries not affected by the Chernobyl accident the radiocaesium intake related to WEF consumption does not constitute a risk, because the dose associated with consumption of fungi is below the recommended limit (Italy, Giovani et al. 2004; Spain, Baeza \& Guillén, 2004; UK, Barnett et al. 1999). For France it has been reported (Kirchner \& Daillant, 1998) that most of the samples of WEF collected have detectable levels of radioactive $\mathrm{Cs}$, but radiation doses to individuals resulting from WEF consumption are dominated by ${ }^{210} \mathrm{~Pb}$ for the majority of WEF sampled.

One last safety concern is the negative consequences derived from some methods of preservation of fungi that diminish their nutritional value (Vetter, 2003a). The 
extremely high $\mathrm{Na}$ levels in canned fungi, 20-30-fold higher than in fresh fungi, is a potentially hazardous factor to some groups of consumers, particularly patients with high blood pressure and generally in consumers with cardiovascular problems. There is also an increase in the concentrations of $\mathrm{Ni}, \mathrm{Cr}$ and $\mathrm{Hg}$. In contrast, the amounts of $\mathrm{K}$, a nutritionally-beneficial mineral, show a 40-80-fold decrease in canned fungi. The most widespread method of preservation of fungi, drying, does not cause any loss of nutritional value, and is thus preferred to canning.

\section{Trends in consumption of wild edible fungi}

Populations in eastern Europe and Russia have a stronger tradition of collecting fungi from the wild than populations from western, northern and central Europe (Wasson \& Wasson, 1957; Druzhinina \& Palma-Oliveira, 2004). Germanic populations have never been great fungi eaters, in contrast to Romans and Slavs (Kardell, 1980).

In the UK the consumption of WEF has always been considered of minor importance. In a survey carried out by Barnett et al. (1999) the median intake rate was found to be $0.75 \mathrm{~kg}$ fresh weight per capita per year, and $60 \%$ of the respondents reported consuming only one species, generally Agaricus campestris. Extrapolation of the results of the questionnaire would suggest that the average intake of WEF in the UK is $0.12 \mathrm{~kg}$ fresh weight per capita per year. According to the respondents of the questionnaire eighty-two species of WEF are being consumed in the UK, although certain species (e.g. chanterelle (Cantharellus cibarius), cep (Boletus edulis), oyster mushroom (Pleurotus ostreatus)) are clearly favoured over others. The survey of Byrom et al. (1995) has reported that fungi (cultivated and wild species) are eaten by only $37 \cdot 3 \%$ of adults throughout the UK. In the study of Fulker et al. (1995) carried out in Cumbria $40.3 \%$ of the participants were reported to consume fungi.

Nevertheless, trends are now changing. In the UK fungi hunters are required to obtain licenses for collecting in Epping Forest, north-east London, because of the increase in commercial picking (Morris, 2002), and similar legislation has been introduced for the New Forest, Hants. In Sweden $>50 \%$ of the population gathers fungi. The custom of eating fungi in Sweden was imported from France and was adopted by the nobility, although not initially by the general public. During years of near-famine there was still a refusal to eat fungi. It was not until the 20th century, when there was migration to the cities and the consequent awareness of other eating habits, that the Swedes began to consider the wild fungus to be worth harvesting and eating (Kardell, 1980).

Trends are also changing in Spain. Basques and Catalans have always been eager fungi consumers, but now interest in picking and eating WEF has spread throughout the country, and populations from other regions where traditionally there was no interest in WEF are now looking forward to the fungi season each year (de Román \& Boa, 2004).

Increasing numbers of the French population have become interested in picking WEF (Berelle, 2002). Fungi pickers can be a serious nuisance in the forest, and in some regions some measures have been taken, such as the establishment of legal regulations for the harvest of WEF, the introduction of a license system for fungi pickers and distribution of leaflets and posters to raise public awareness about good harvesting practices and the threats of overexploitation.

In contrast, the tradition of gathering and consuming WEF among rural populations in countries such as India is on the decline because of growing urbanisation and the associated changes in food habits. It has become necessary to document the nutritional quality of traditionallyconsumed WEF in order to retain this valuable information (Agrahar-Murugkar \& Subbulakshmi, 2005).

Some ethnomycological studies have shown that in Africa knowledge about fungi is widespread and extensive, although it varies between regions. However, this widespread knowledge does not imply a high social valuation of fungi or a high consumption (Yorou \& De Kesel, 2001; Kuyper, 2002). Although WEF could be useful in helping to overcome extreme food shortages in this continent, there appears to be only one report of the use of fungi as an emergency food (Wilson et al. 1989), even though they are routinely used at times of low food availability in countries like Malawi.

An overview of the uses and importance of WEF to global populations has been published by Boa (2004), in which there are records of 1200 species being consumed in eighty-five countries and more detailed information on the consumption of WEF worldwide.

\section{Concluding remarks}

Fungi have a balanced and high nutritional value, are rich sources of protein and fibre, are low in fat and make a useful contribution to mineral and vitamin intake. They have potential as a food source in situations of food shortage and as nutritional additions in the daily diet. It is anticipated that, in the future, fungi will have increasing importance in medicine and biotechnology because of their unique biosynthetic capabilities and metabolic products. Most safety concerns can be overcome by exercising caution when eating WEF. The present paper provides evidence of the considerable potential of WEF as a food source that should be given more consideration, particularly by nutritionists.

\section{Aknowledgements}

The authors wish to thank The Nutrition Society and The Royal Botanic Gardens, Kew for the invitation to present this paper at the Nutrition Society Summer Meeting 2005. M. de R. received support from the Spanish Ministry of Education and Science through a postdoctoral fellowship.

\section{References}

Agrahar-Murugkar D \& Subbulakshmi G (2005) Nutritional value of edible mushrooms collected from the Khasi hills of Meghalaya. Food Chemistry 89, 599-603. 
Alofe FV (1991) Amino acids and trace minerals of three edible wild mushrooms from Nigeria. Journal of Food Composition and Analysis 4, 167-174.

Alofe FV, Odevemi O \& Oke OL (1996) Three edible wild mushrooms from Nigeria: Their proximate and mineral composition. Plant Foods for Human Nutrition 49, 63-73.

Alonso J, García MA, Pérez-López M \& Melgar MJ (2003) The concentrations and bioconcentration factors of $\mathrm{Cu}$ and $\mathrm{Zn}$ in edible mushrooms. Archives of Environmental Contamination and Toxicology 44, 180-188.

Alonso J, Salgado MJ, García MA \& Melgar MJ (2000) Accumulation of $\mathrm{Hg}$ in edible macrofungi: influence of some factors. Archives of Environmental Contamination and Toxicology 38, 158-162.

Baeza A \& Guillén FJ (2004) Dose due to mushroom ingestion in Spain. Radiation Protection Dosimetry 111, 97-100.

Barcan VS, Kovnatsky EF \& Smetannikova MS (1998) Absorption of heavy metals in wild berries and edible mushrooms in an area affected by smelter emissions. Water, Air, \& Soil Pollution 103, 173-195.

Barnett CL, Beresford NA, Self PL, Howard BJ, Frankland JC, Fulker MJ, Dodd BA \& Marriott JVR (1999) Radiocaesium activity concentrations in the fruit-bodies of macrofungi in Great Britain and an assessment of dietary intake habits. The Science of the Total Environment 231, 67-83.

Berelle G (2002) Organiser le ramassage des champignons (Organising the collection of mushrooms). Forets de France 456, 31 .

Boa E (2004) Wild Edible Fungi. A Global Overview of Their Use and Importance to People. Non-wood Forest Products Series no. 17. Rome: FAO.

Bokhary HA \& Parvez S (1993) Chemical composition of desert truffles Terfezia claveryi. Journal of Food Composition and Analysis 6, 285-293.

Botha WJ \& Eicker A (1992) Nutritional value of Termitomyces mycelial protein and growth of mycelium on natural substrates. Mycological Research 96, 350-354.

Byrom J, Robinson CA, Simmonds JR \& Walters CB (1995) Food consumption rates for use in generalised radiological dose assessments. Journal of Radiological Protection 15, 335-342.

Caglarirmak N, Unal K \& Otles S (2002) Nutritional value of edible wild mushrooms collected from the Black Sea region of Turkey. Micologia Aplicada International 14, 1-5.

Cheung PC-K (1997) Dietary fibre content and composition of some edible fungi determined by two methods of analysis. Journal of the Science of Food and Agriculture 73, 55-260.

Coli R, Coli AM, Granetti B \& Damiani P (1988) The nutritional value and protein quality of the carpophores of Boletus aereus, Boletus edulis, Boletus pinicola and Boletus reticulatus. Annali della Facolta di Agraria, Universita degli Studi di Perugia 42, 873-898.

de Román M \& Boa E (2004) Collection, marketing and cultivation of edible fungi in Spain. Micologia Aplicada International 16, 15-23.

Díez VA \& Álvarez A (2001) Compositional and nutritional studies on two wild edible mushrooms from northwest Spain. Food Chemistry 75, 417-422.

Druzhinina I \& Palma-Oliveira JM (2004) Radioactive contamination of wild mushrooms: a cross-cultural risk perception study. Journal of Environmental Radioactivity 74, 83-90.

Eisenhut R, Fritz D \& Tiefel P (1995) Investigations on nutritionally valuable constituents (mineral substances, amino acids, aromatic substances) of Hericium erinaceus (Bull.: Fr.) Pers. Gartenbauwissenschaft 60, 212-218.
Falandysz J, Bona H \& Danisiewicz D (1994) Silver content of wild-grown mushrooms from northern Poland. Zeitschrift für Lebensmittel-Untersuchung und-Forschung 199A, 222-224.

Falandysz J, Jedrusiak A, Lipka K, Kannan K, Kawano M, Gucia M, Brzostowski A \& Dadej M (2004) Mercury in wild mushrooms and underlying soil substrate from Koszalin, North-central Poland. Chemosphere 54, 461-466.

Fulker MJ, McKay K, John C \& Jackson D (1995) Radioactivity in Terrestrial Wild Foods Near Sellafield. Final Report to the Ministry of Agriculture Fisheries and Food. Moor Row, Cumbria: Westlakes Research (Trading) Ltd.

García MA, Alonso J, Fernández MI \& Melgar MJ (1998) Lead content in edible wild mushrooms in Northwest Spain as indicator of environmental contamination. Archives of Environmental Contamination and Toxicology 34, 330-335.

Giovani C, Garavaglia M \& Scruzzi E (2004) Radiocaesium in mushrooms from northeast Italy, 1986-2002. Radiation Protection Dosimetry 111, 377-383.

Hosford D, Pilz D, Molina M \& Amaranthus M (1997) Ecology and Management of the Commercially Harvested American Matsutake Mushroom. General Technical Report PNW-GTR412. Portland, OR: US Department of Agriculture, Forest Service, Pacific Northwest Research Station.

Ikekawa T (2001) Beneficial effects of edible and medicinal mushrooms on health care. International Journal of Medicinal Mushrooms 3, 291-298.

Ilievska BP \& Petrovska BB (2000) Amino acid analysis of some Macedonian edible wild mushrooms. Acta Pharmaceutica 50, 141-149.

Isiloglu M, Merdivan M \& Yilmaz F (2001) Heavy metal contents in some macrofungi collected in the northwestern part of Turkey. Archives of Environmental Contamination and Toxicology 41, 1-7.

Joint Food Standards and Safety Group (2000) Multi-element Survey of Wild Edible Fungi and Blackberries. MAFF UK Food Surveillance Information Sheet no. 199. London: H. M. Stationery Office.

Kardell L (1980) Forest berries and mushrooms - an endangered resource? Ambio 9, 241-247.

Kirchner G \& Daillant O (1998) Accumulation of ${ }^{210} \mathrm{~Pb},{ }^{26} \mathrm{Ra}$ and radioactive cesium by fungi. The Science of the Total Environment 222, 63-70.

Kuyper TW (2002) Ethnomycology in Africa. Coolia 45, 191-197.

Lakshmi B, Tilak JC, Adhikari S, Devasagayam TPA \& Janardhanan KK (2004) Evaluation of antioxidant activity of selected Indian mushrooms. Pharmaceutical Biology 42, 179-185.

León-Guzmán MF, Silva I \& López MG (1997) Proximate chemical composition, free amino acid contents, and free fatty acid contents of some wild edible mushrooms from Querétaro, Mexico. Journal of Agricultural and Food Chemistry 45, $4329-4332$.

Ling C, Hua J, Chen H \& Feng L (1990) Studies on the nutritional value and biological effect of Collybia velutipes. Acta Nutrimenta Sinica 12, 178-184.

Longvah T \& Deosthale YG (1998) Compositional and nutritional studies on edible wild mushroom from northeast India. Food Chemistry 63, 331-334.

Manzi P, Aguzzi A \& Pizzoferrato L (2001) Nutritional value of mushrooms widely consumed in Italy. Food Chemistry 73, 321-325.

Mattila PH, Piironen VI, Uusi-Rauva EJ \& Koivistoinen PE (1994) Vitamin D contents in edible mushrooms. Journal of Agricultural and Food Chemistry 42, 2449-2453.

Melgar MJ, Alonso J, Pérez-López M \& García MA (1998) Influence of some factors in toxicity and accumulation of $\mathrm{Cd}$ 
from edible wild macrofungi in NW Spain. Journal of Environmental Science and Health B33, 439-455.

Michelot D, Poirier F \& Melendez-Howell LM (1999) Metal content profiles in mushrooms collected in primary forests of Latin America. Archives of Environmental Contamination and Toxicology 36, 256-263.

Molitoris HP (2002) Pilze in Medizin, Folklore und Religion (Mushrooms in medicine, folklore and religion). Feddes Repertorium 113, 165-182.

Morris S (2002) Mushroom hunters forced to get licenses. The Guardian 23 September issue, 9.

Mukhiibi J (1973) The nutritional value of some Uganda mushrooms. Acta Horticulturae 33, 171-176.

Ooi V (2001) Pharmacological studies on certain mushrooms from China. International Journal of Medicinal Mushrooms 3, 341-354.

Outila TA, Mattila PH, Piironen VI \& Lamberg-Allardt CJE (1999) Bioavailability of vitamin D from wild mushrooms (Cantharellus tubaeformis) as measured with a human bioassay. American Journal of Clinical Nutrition 69, 95-98.

Rudawska M \& Leski T (2005) Macro- and microelement contents of fruiting bodies of wild mushrooms from the Notecka forest in west-central Poland. Food Chemistry 92, 499-506.

Sadler M (2003) Nutritional properties of edible fungi. Nutrition Bulletin 28, 305-308.

Sanmee R, Dell B, Lumyong P, Izumori K \& Lumyong S (2003) Nutritive value of popular wild edible mushrooms from northern Thailand. Food Chemistry 82, 527-532.

Seeger R, Trumpfheller S \& Schweinshaut P (1983) On the occurrence of sodium in fungi. Deutsche Lebensmittel-Rundschau 79, 80-87.

Solomko EF, Panchenko LP \& Sil'chenkova RK (1984) Lipid content and fatty acid composition of an edible higher fungus, the oyster mushroom Pleurotus ostreatus (Fr.) Kummer. Applied Biochemistry and Microbiology 20, 224-229.

Statkiewicz U \& Gayny B (1994) Contamination of some wild edible fungi with metals. Roczniki Panstwowego Zakadu Higieny 45, 27-35.

Svoboda L, Zimmermannová K \& Kalac P (2000) Concentrations of $\mathrm{Hg}, \mathrm{Cd}, \mathrm{Pb}$ and $\mathrm{Cu}$ in fruiting bodies of edible mushrooms in an emission area of a $\mathrm{Cu}$ smelter and a $\mathrm{Hg}$ smelter. The Science of the Total Environment 246, 61-67.

Tudge C (2001) The best medicine. New Scientist 172, 40-43.
Vasser SI, Hrodzyns'ka HA \& Lyuhin VO (1992) Accumulation of radioactive elements by macromycetes of Ukrainian Polessie. Ukrayins'kyi Botanichnyi Zhurnal 49, 79-86.

Vetter J (1994) Phosphorus content of edible wild mushrooms of Hungary. Acta Alimentaria 233(3), 331-336.

Vetter J (1999) Vanadium content of some common edible, wild mushroom species. Acta Alimentaria 28, 39-48.

Vetter J (2003a) Chemical composition of fresh and conserved Agaricus bisporus mushroom. European Food Research and Technology 217, 10-12.

Vetter J (2003b) Data on sodium content of common edible mushrooms. Food Chemistry 81, 589-593.

Vetter J (2005) Lithium content of some common edible wildgrowing mushrooms. Food Chemistry 90, 31-37.

Vetter J \& Berta E (1997) Mercury content of some wild edible mushrooms. Zeitschrift für Lebensmittel-Untersuchung und -Forschung 205A, 316-320.

Wasson RG (1968) Soma: Divine Mushroom of Immortality. The Hague, The Netherlands: Mouton.

Wasson VP \& Wasson RG (1957) Mushrooms, Russia and History, vol. 1-2. New York: Pantheon Books.

Wilson K, Cammack D \& Shumba F (1989) Food Provisioning Amongst Mozambican Refugees in Malawi. A Study of Aid, Livelihood and Development. A Report Prepared for the World Food Programme. Oxford: Oxford University, Refugee Studies Programme.

Wong JLG, Thornber K \& Baker N (2001) Resource Assessment of Non-wood Forest Products. Experience and Biometric Principles. Non-wood Forest Products Series no.13. Rome: FAO.

Yildiz A, Yesil ÖF, Yavuz Ö \& Karakaplan M (2005) Organic elements and protein in some macrofungi of south east Anatolia in Turkey. Food Chemistry 89, 605-609.

Yorou SN \& De Kesel A (2001) Indigenous ethnomycological knowledge of the Nagot people from the centre of Benin (West Africa). Systematics and Geography of Plants 71, 627-637.

Zimmermannova K, Svoboda L \& Kalac P (2001) Mercury, Cd, $\mathrm{Pb}$, and $\mathrm{Cu}$ contents in fruiting bodies of selected edible mushrooms in contaminated Middle Spis region, Slovakia. Ekologia (Bratislava) 20, 440-446.

Zrodowski Z (1995) The influence of washing and peeling of mushrooms (Agaricus bisporus) on the level of heavy metal contamination. Polish Journal of Food and Nutrition Sciences 4, 26-33. 